\author{
Dr Milorad Savković, \\ dipl. inž.
Vojnotehnički institut, \\ Beograd
}

\section{ISPITIVANJE PIROPATRONA I RAKETNOG MOTORA PILOTSKOG SEDIŠTA}

UDC: $621.453: 629.7 .047 .2$

Rezime:

Raketni motor pilotskog sedišta ima složen geometrijski oblik, tako da njegov potisak deluje pod određenim uglom u odnosu na ravan simetrije pilotskog sedišta. Radi određivanja intenziteta i napadne linije potiska izvršen je veći broj eksperimenata. Meren je potisak raketnog motora na višekomponentnom opitnom stolu. Letno ispitivanje pilotskog sedišta obavljeno je pomoću lutke koja simulira masu pilota. Takođe, analizirano je letno ispitivanje pilotskog sedišta u početnom periodu katapultiranja za vreme rada raketnog motora. Obrađeni su i rezultati merenja ubrzanja, koji su korišćeni za određivanje karakteristika leta pilotskog sedišta. U radu je prikazan teorijski model kretanja sedišta.

Ključne reči: pilotsko sedište, katapultiranje pilotskog sedišta, raketni motor, ubrzanje.

\title{
TESTING PYROCARTRIGES AND THE ROCKET MOTOR OF THE EJECTION SEAT
}

Summary:

Due to a complex geometrical shape of the rocket motor of the ejection seat, the rocket motor thrust occurs under certain angle in relation to the plane of symmetry of the ejection seat. A number of tests were carried out in order to determine thrust intensity and angle of attack. The rocket motor thrust was measured on the multicomponent test stand. The ejection seat whit a dummy simulating a mass of a pilot was tested during ejection. The paper presents an analysis of the ejection seat flight in the initial phase of ejection, during the rocket motor running. The results of the acceleration read-outs were processed and then used for the determination of the characteristics of the ejection seat flight. A theoretical model of the ejection seat flight is given in the paper.

Key words: ejection seat, ejection seat egression, rocket motor, acceleration.

\section{Uvod}

U sistemu spasavanja pilota iz aviona izbacivo sedište obezbeđuje više različitih funkcija od kojih je najznačajnije prinudno napuštanje aviona (katapultiranje). Cilj katapultiranja jeste da se pilot zajedno sa sedištem odbaci od aviona na bezbednu udaljenost i da se ostvare uslovi za otvaranje padobrana.

Ceo proces, od trenutka aktiviranja izbacivog sedišta do trenutka prizemljenja, potpuno je automatizovan $1,2,3$ i ostvaruje se aktiviranjem pojedinih pirotehničkih elemenata po određenom redosledu. Pirotehnički elementi su piropatrone i raketni motor. Na početku katapultiranja, pod dejstvom piropatrona, sedište klizi duž vođice teleskopske cevi. Nakon razdvajanja sedišta i teleskopa aktivira se raketni motor. Rad raketnog motora omogućava da se pilot pravovremeno nađe na bezbednoj udaljenosti od letelice i da ima odgovarajuću brzinu za pravilnu funkciju padobrana. 
Savremena pilotska sedišta sa raketnim motorom omogućavaju spasavanje pilota i pri nultoj visini i nultoj brzini aviona. Brzina sedišta u trenutku aktiviranja padobrana mora biti veća od kritične brzine za otvaranje padobrana, bez obzira na prethodnu brzinu aviona. Tokom prizemljenja na određenoj visini dolazi do razdvajanja pilota i sedišta.

Piropatrone i raketni motor pilotskog sedišta moraju biti vrlo pouzdani 14 . Piropatrone treba da ostvare pritisak gasovitih produkata sagorevanja, a raketni motor potisak, sa minimalnim odstupanjem od nominalne vrednosti. Mlaznice raketnog motora su zakošene u dve ravni, tako da potisak ne leži u ravni simetrije motora, čime je postignuto da se putanje aviona i pilotskog sedišta razilaze. Zbog toga je, tokom razvoja i provere kvaliteta piropatrona i raketnih motora, veoma važno da se izvrši korektno ispitivanje pritiska kod piropatrona, odnosno potiska raketnog motora.

\section{Rezultujući potisak i moment raketnog motora pilotskog sedišta}

Određivanje vektora potiska raketnog motora izbacivog pilotskog sedišta podrazumeva određivanje intenziteta $\mathrm{i}$ napadne linije ovog vektora na osnovu izmerenih veličina na višekomponentnom opitnom stolu 5, 6, 7 na kojem se obavlja ispitivanje (sl. 1).

Tokom rada raketnog motora na opitnom stolu mere se komponente $\left(F_{x}\right.$, $F_{y}$ i $F_{z}$ glavnog vektora sistema $F_{R}(t) i$ komponente $\left(\mathrm{M}_{\mathrm{x}}, \mathrm{M}_{\mathrm{y}} \mathrm{i} \mathrm{M}_{\mathrm{z}}\right)$ glavnog momenta sistema $\mathrm{M}(\mathrm{t})$. Ovi vektori svedeni su na redukcionu tačku $\mathrm{O}$, a komponente vektora date su za koordinatne ose $\mathrm{x}, \mathrm{y} \mathrm{i}$ z, prema slici 2.

Obradom rezultata merenja dobijaju se srednje vrednosti $F_{R} i \quad M$, čiji intenziteti pomnoženi sa efektivnim vremenom $t_{\text {ef }}$ rada motora daju integrale intenziteta tih veličina.

Srednje vrednosti glavnih vektora sile i momenta određuju se iz relacija:

$$
\begin{aligned}
& \bar{F}_{R}=\frac{1}{t_{e f}} \cdot \int_{0}^{t_{u}} \sqrt{F_{x}^{2}+F_{y}^{2}+F_{z}^{2}} \cdot d t \\
& \bar{M}=\frac{1}{t_{e f}} \cdot \int_{0}^{t_{u}} \sqrt{M_{x}^{2}+M_{y}^{2}+M_{z}^{2}} \cdot d t
\end{aligned}
$$

Rezultujuća sila je po intenzitetu jednaka glavnom vektoru sile i leži na centralnoj osi sistema. Rezultujuća sila i

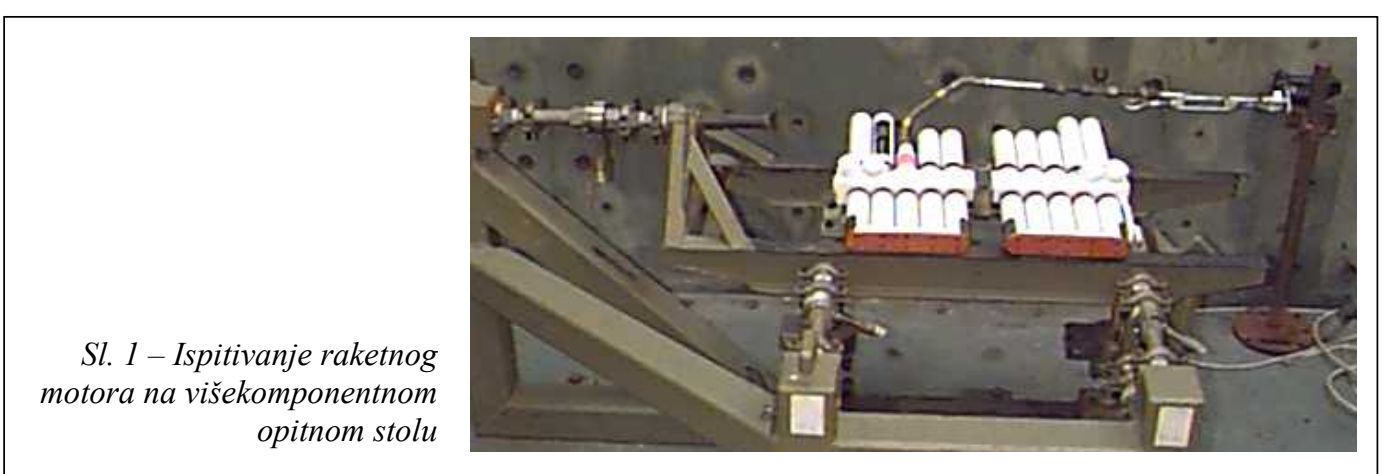




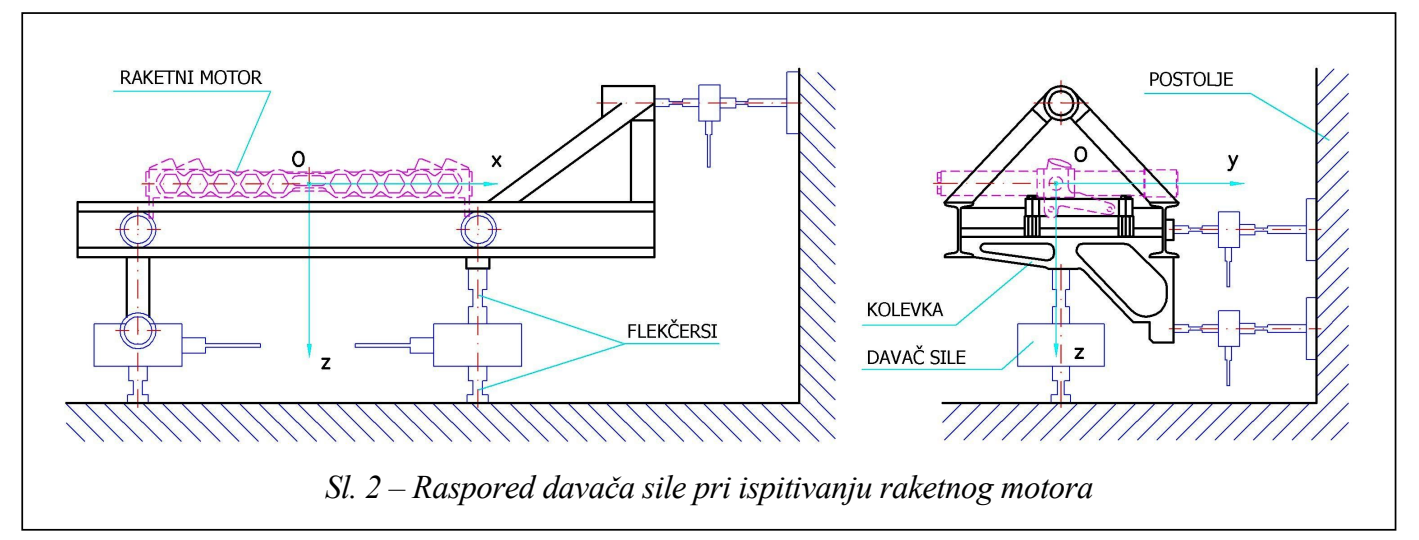

moment nalaze se pod određenim prostornim uglom koji se određuje iz relacije 4,7 :

$$
=\arccos
$$$$
\frac{F_{x} \cdot M_{x}+F_{y} \cdot M_{y}+F_{z} \cdot M_{z}}{\sqrt{F_{x}^{2}+F_{y}^{2}+F_{z}^{2}} \cdot \sqrt{M_{x}^{2}+M_{y}^{2}+M_{z}^{2}}}
$$

Izmerene vrednosti rezultujuće sile $i$ momenta

Radi određivanja intenziteta i pravca delovanja potiska izvršen je veći broj statičkih opita sa originalnim i domaćim raketnim motorima pilotskih sedišta $[9$, $10,11]$. U funkciji vremena merene su tri komponente vektora potiska i momenti oko tri ose sistema. Odgovarajućom obradom rezultata merenja $[4,5,6,7]$, za svaki opit određeni su totalni impuls rezultujuće sile, integral glavnog momenta i srednja vrednost ugla između glavnog vektora sila i momenta.

U eksperimentima je dobijena zadovoljavajuća reproduktivnost rezultata izmerenih veličina sila i momenata sa odstupanjima od nekoliko procenata. Ugao između glavnog vektora sile i momenta je $\quad 90^{\circ}$. Utvrđeno je da se odstupanje ugla $\mathrm{u}$ realizovanim opitima kretalo $\mathrm{u}$ granicama 1 . Tipični dijagrami rezultujuće sile i momenta raketnog motora pilotskog sedišta u funkciji vremena prikazani su na slici 3.

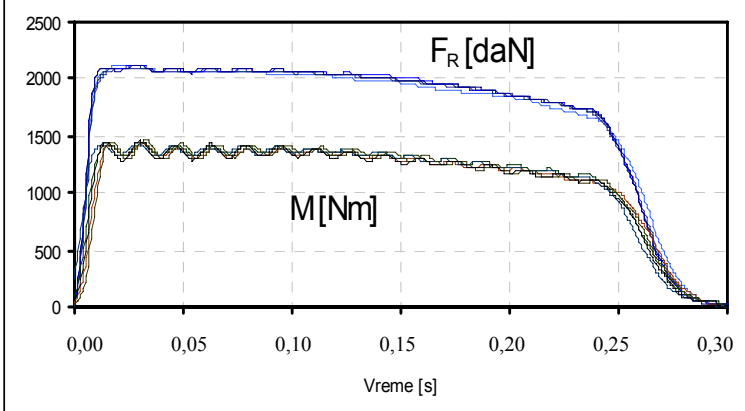

Sl. 3 - Rezultujuće sile i momenti raketnih motora pilotskih sedišta 


\section{Kretanje pilotskog sedišta u početnom periodu katapultiranja}

Raketni motor aktivira se neposredno posle dejstva piropatrona koje su zadužene za ostvarenje početne visine i brzine sedišta. U vreme dejstva piropatrona sedište je vezano za avion i kreće se po balističkom katapultu. Balistički katapult sadrži teleskopske cevi koje se izvlače i služe kao vođice. Međutim, u trenutku kada se aktivira raketni motor sedište je slobodno. Ako je avion bio u pokretu u trenutku započinjanja katapultiranja, sedište je i pod dejstvom intenzivne vazdušne struje. Sile koje deluju na sedište usmeravaju njegovo kretanje. Najintenzivnija sila je potisak raketnog motora. Otpor vazduha i težina sedišta, iako su manje sile, znatno utiču na trajektoriju sedišta.

\section{Teorijska putanja}

Potisak raketnog motora deluje na sistem sedište-pilot sa rezultujućom silom i momentom, koji se nalaze pod određenim prostornim uglom u odnosu na silu težine i otpor vazduha.

Za teorijsku analizu kretanja usvaja se, prema slici 4, pravougli koordinatni sistem (C, , , z) sa koordinatnim početkom na avionu, gde se nalazio centar mase sedišta zajedno sa pilotom $u$ početnom trenutku. Uvode se određena uprošćenja, kao što je pretpostavka o kretanju sedišta kao materijalne tačke u vertikalnoj ravni $\epsilon$ u kojoj deluje rezultujuća sila i nalazi se koordinatni početak, tačka C. Model pretpostavlja da se težište (tačka C) sistema sedišta, zajedno sa pilotom i opremom, nalazi u ravni dejstva rezultujuće sile. Ove pretpostavke mogu da važe samo u prvom približenju, a prihvatlji-

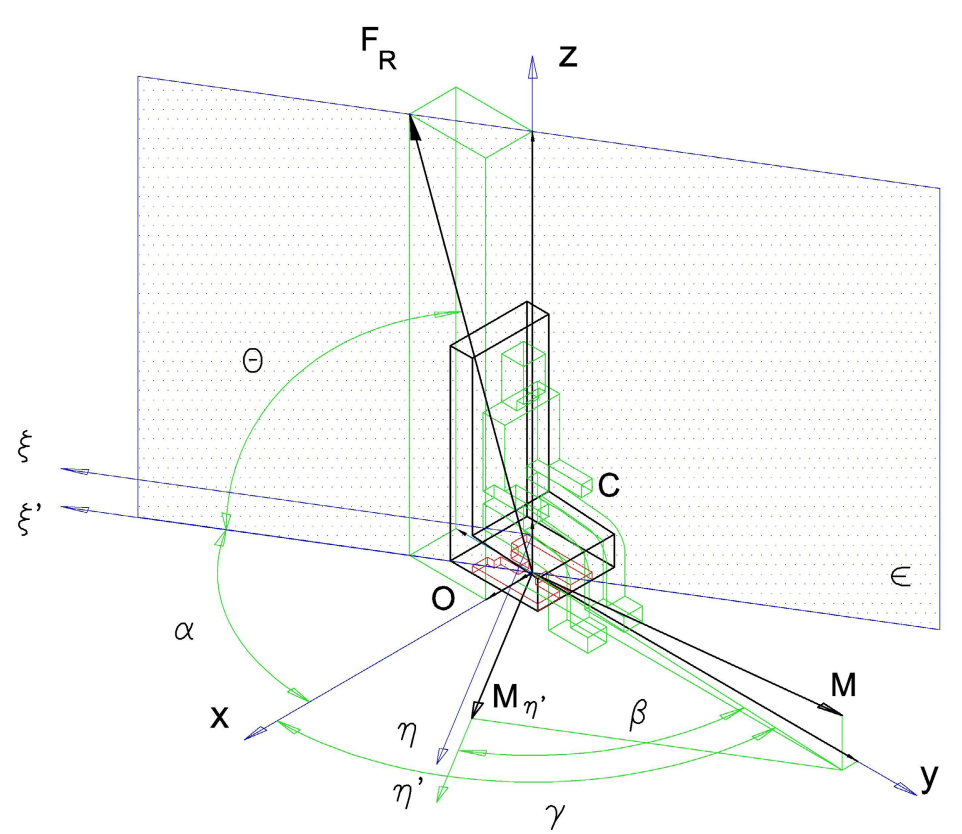

Sl. 4 - Šematski prikaz pilotskog sedišta u početnom trenutku aktiviranja raketnog motora u procesu katapultiranja 
ve su, jer se analizira jedan kratak deo trajektorije sedišta u periodu rada raketnog motora, koji traje oko $0,3 \mathrm{~s}$.

Rezultujuća sila i moment raketnog motora, prema radu 7 , određeni su statičkim ispitivanjem na višekomponentnom opitnom stolu za koordinatni sistem raketnog motora $(\mathrm{O}, \mathrm{x}, \mathrm{y}, \mathrm{z})$.

Vertikalna ravan $C$, u kojoj leži rezultujuća sila, preseca ravan $\mathrm{xOz}$ (sl. 4), pod uglom:

$$
=\operatorname{arctg} \frac{F_{Y}}{F_{X}}
$$

Pretpostavlja se da se tačka C, koja predstavlja težište sistema sedište-pilot, nalazi u ravni $€$. Početni ugao dejstva rezultujuće sile u ravni $€$ u odnosu na osu $O$ ' je:

$$
{ }_{0}=\operatorname{arctg} \frac{F_{Z}}{\sqrt{F_{X}^{2}+F_{Y}^{2}}}
$$

Projekcija rezultujućeg momenta $M$ na osu $O$ ', koja je upravna na ravan $€$ je:

$$
M_{\eta^{\prime}}=\sqrt{M_{X}^{2}+M_{Y}^{2}} \cdot \cos \beta
$$

gde su:

$$
\beta=\gamma-\alpha-\frac{\pi}{2} \text { i } \gamma=\operatorname{arctg} \frac{M_{Y}}{M_{X}}
$$

Posle zamene i translacije momenta na paralelnu osu C dobija se ukupni moment koji deluje u težišnoj tački sistema sedište-pilot i upravan je na ravan $C$. Taj moment iznosi:

$$
\begin{aligned}
& M_{\eta}=\frac{M_{Y} \cdot F_{X}-M_{X} \cdot F_{Y}}{\sqrt{F_{X}^{2}+F_{Y}^{2}}}-e . \\
& \cdot \sqrt{F_{X}^{2}+F_{Y}^{2}+F_{Z}^{2}}
\end{aligned}
$$

gde je $e$ - udaljenost rezultujuće sile od težišta sistema.

U usvojenom modelu sistem sedište-pilot predstavljen je masom $\mathrm{m}$ promenljivog intenziteta, konstantnim momentom inercije $I$ i poprečnim presekom $A_{S}$. Moment inercije određen je pomoću programa na PC računaru, korišćenjem solid modeliranja sedišta, raketnog motora i pilota (sl. 5). Za osu C određen je moment inercije svakog od tih sklopova.

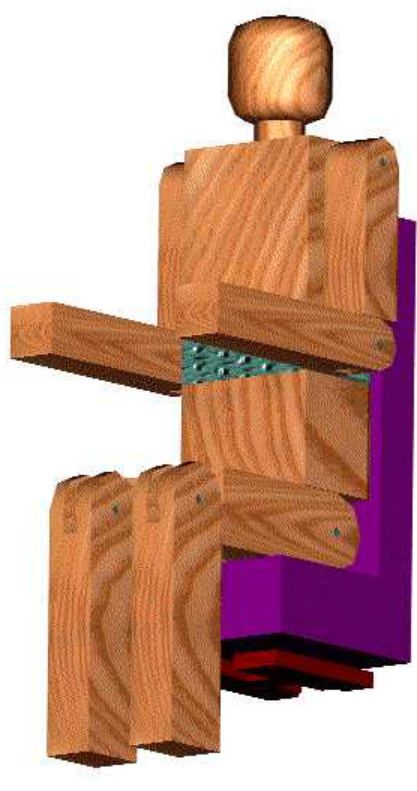

Sl. 5 - Lutka-model pilota

\section{Diferencijalne jednačine kretanja sedišta}

$\mathrm{U}$ koordinatnom sistemu $(\mathrm{C}, \mathrm{,}, \mathrm{z})$, koji je vezan za avion, tačka $\mathrm{C}$ predstavlja težište sistema pilot-sedište u početnom trenutku neposredno pre početka katapultiranja.

Diferencijalne jednačine 8 kretanja sedišta pod dejstvom raketnog moto$\mathrm{ra}, \mathrm{u}$ ravni $\mathrm{Cz}$, su: 


$$
\begin{aligned}
& \frac{d V}{d t}=\frac{F_{R}}{m} \cdot \cos \varphi-\frac{1}{2 \cdot m} . \\
& \cdot A_{S} \cdot \rho \cdot V^{2} \cdot C_{D}\left(M_{a}\right)-g \cdot \sin \theta \\
& \frac{d \theta}{d t}=\frac{F_{R}}{m} \cdot \sin \varphi \cdot \frac{1}{V}-g \cdot \cos \theta \cdot \frac{1}{V}, \\
& \frac{d \xi}{d t}=V \cdot \cos \theta, \frac{d z}{d t}=V \cdot \sin \theta, \\
& \frac{d \omega}{d t}=\frac{M_{\eta}}{I_{\eta}}, \frac{d \varphi}{d t}=\omega, \frac{d m}{d t}=-\frac{F_{R}}{I_{S P}}
\end{aligned}
$$

Veličine koje se modelom određuju $u$ ravni $\epsilon$ su: brzina sedišta $V$, ugao koji tangenta na trajektoriju putanje zaklapa sa osom C , koordinate i z položaja sedišta, pređeni put s, ugao i ugaona brzina sedišta , kao i promena mase sedišta m. Rešenje diferencijalnih jednačina omogućava teorijsku analizu promene ubrzanja, brzine i pređenog puta sedišta.

U rešavanju sistema diferencijalnih jednačina polazi se od toga da su poznati uslovi kretanja kroz vazduh, koeficijent otpora $\mathrm{C}_{\mathrm{D}}\left(\mathrm{M}_{\mathrm{a}}\right)$ u funkciji Mahovog broja $\mathrm{M}_{\mathrm{a}}$, gustina vazduha $\mathrm{i}$ gravitaciona konstanta g. Ispitivanjem na opitnom stolu utvrđeni su: specifični impuls $\mathrm{I}_{\mathrm{sp}}$ raketnog motora, rezultujući potisak $F_{R}(t) i$ projekcija glavnog momenta $\mathrm{M}(\mathrm{t})$.

Usvajaju se sledeći početni uslovi:

- ${ }_{0}$ i z $z_{0}$, početni položaj sedišta u ravni $\mathrm{C}$ u trenutku početka rada motora, odnosno na kraju rada piropatrona po napuštanju teleskopske cevi balističkog katapulta,

- 0 , početni ugao rezultujuće sile raketnog motora u odnosu na osu C , koji približno odgovara uglu brzine sedišta na kraju rada piropatrona,

- $\mathrm{V}_{0}$, početna brzina sedišta pod dejstvom piropatrona,
${ }_{-}{ }_{0}=0 \mathrm{i} \quad{ }_{0}=0$, početni ugao i ugaona brzina,

$-\mathrm{m}=\mathrm{m}_{0}$, početna masa koja odgovara ukupnoj masi sedišta i pilota sa opremom. Pod masom sedišta podrazumeva se masa letnog dela sedišta i raketnog motora sa pogonskim punjenjem.

\section{Rezultat rešenja diferencijalnih jednačina}

Sistem diferencijalnih jednačina rešavan je metodom Runge-Kutta 12 . Na dijagramima (slika 6) prikazani su rezultati izračunatog vremenskog toka brzine V i puta s u slučaju katapultiranja sedišta pri nultoj visini i nultoj brzini aviona.

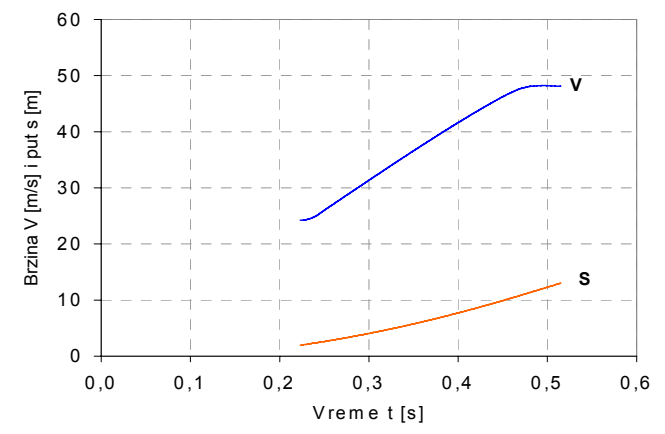

Sl. 6 - Karakteristike leta sedišta iz rešenja diferencijalnih jednačina

Kretanje pilotskog sedišta je složeno, ali se uz određena uprošćenja može prihvatiti model kretanja u jednoj ravni, kako je prikazano u radu. Prosečna vrednost ubrzanja je oko $105 \mathrm{~m} / \mathrm{s}^{2}$, a zaokretanje oko ose iznosi-8,3 .

\section{Letno ispitivanje pilotskog sedišta}

Poligonsko ispitivanje (sl. 7) vršeno je lansiranjem pilotskog sedišta u statičkim uslovima, slično uslovima katapultiranja pilota pri nultoj visini i brzini aviona. 


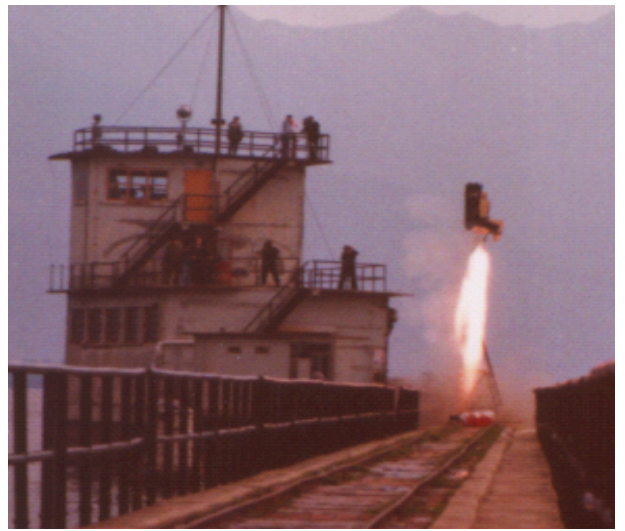

Sl. 7 - Katapultiranje pilotskog sedišta

$\mathrm{Za}$ te potrebe izrađena je lansirna rampa u krutom spoju sa podlogom. $\mathrm{Na}$ lansirnu rampu montiran je balistički katapult sa sedištem i drvenom lutkom koja ima masu, položaj težišta i momente inercije slične pilotu (sl. 5). Lutka je za sedište vezana standardnim pilotskim vezama. Pri ispitivanju vršeno je merenje ubrzanja i praćenje leta sedišta sa više ultrabrzih kamera [13].

\section{Merenje ubrzanja}

Ubrzanje je mereno na jednom mernom mestu i to na vrhu naslona sedišta sa desne strane pilota. Pretvarač ubrzanja i sedište bili su u čvrstoj vezi. Merni lanac sastojao se od: pretvarača ubrzanja na principu merne trake, pojačivača na principu mernog mosta, mernog magnetofona i kablova za povezivanje pojedinih elemenata mernog lanca.

Vremenski tok ubrzanja, reprodukovan sa trake mernog magnetofona, digitalizovan je pomoću digitalnog osciloskopa i obrađen je pomoću posebnog programa. Merni zapis ubrzanja prikazan je na slici 8. Vremenski tok izmerenog ubrzanja, pored jednosmerne komponente, sadrži i više harmonika (naizmeničnih komponenti) visokog intenziteta oscilovanja koji su generisani usled impulsne pobude sistema pilot-sedište i znatno zavise od načina ispitivanja (karakter veze elemenata u sistemu i uticaj položaja mernog mesta).

Jednosmerna komponenta ubrzanja dolazi od kretanja sistema pilot-sedište, dok su naizmenične komponente lokalnog karaktera i nastaju od oscilovanja tačaka sistema oko svog ravnotežnog položaja. Naizmenično ubrzanje viših učestanosti, kao u ovom slučaju, nije opasno po ljude pri jednokratnom izlaganju.

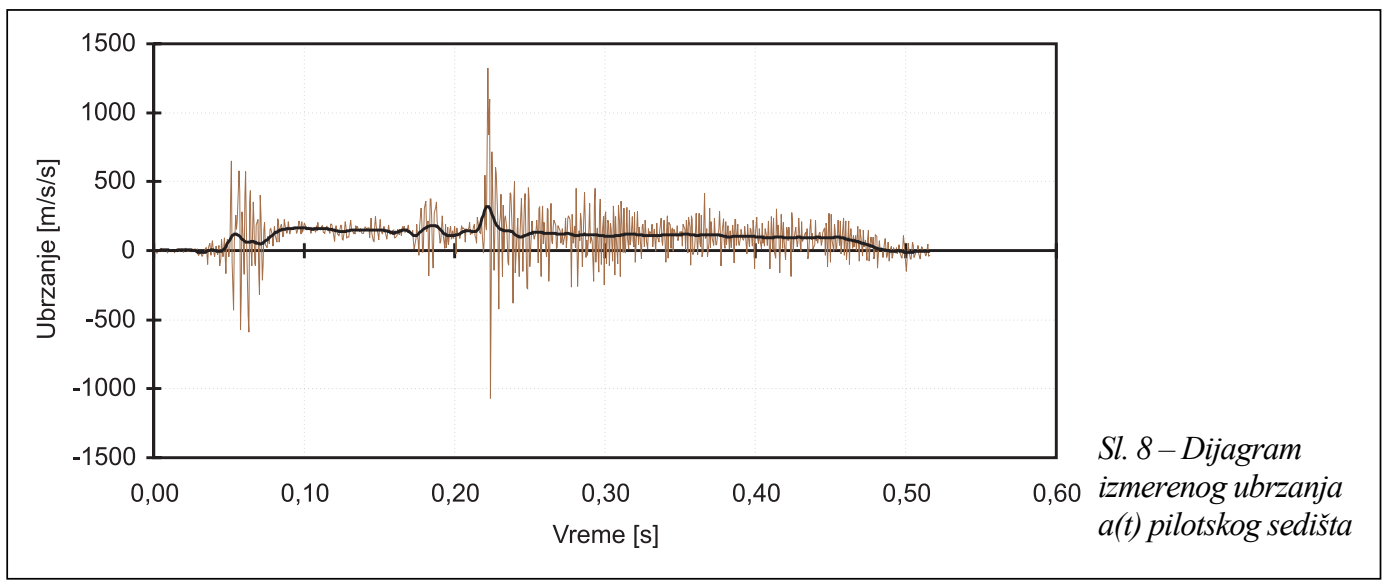




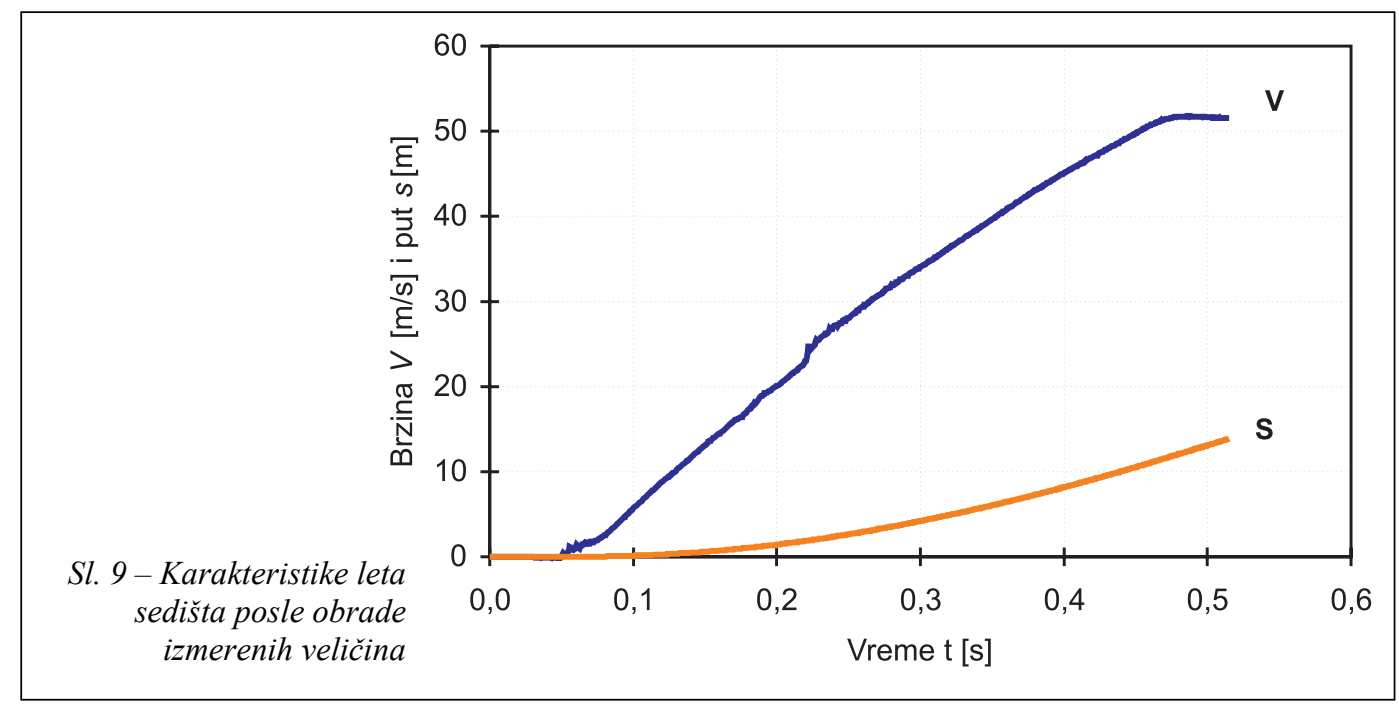

Obavljena je obrada vremenskog toka ubrzanja, koja pokazuje da je zanemarljiv uticaj naizmeničnih komponenti ubrzanja na brzinu i put sistema pilot-sedište. Obrada, u osnovi, sadrži dvostruku integraciju izmerenog ubrzanja, pri čemu prva integracija daje brzinu, a druga integracija put sistema pilot-sedište (sl. 9).

Iz dijagrama sa slike 9 vidi se da je brzina sedišta tokom većeg dela puta bila veoma stabilna, sem u trenutku odvajanja sedišta od katapulta i da je imala naglašeno linearan karakter i to sa jednim koeficijentom pravca od dejstva piropatrona $\mathrm{i}$ sa drugim koeficijentom pravca od dejstva raketnog motora.

Vrednosti ovih koeficijenata pravaca predstavljaju prosečnu vrednost ubrzanja koje deluje na pilota u toku katapultiranja.

\section{Upoređenje teorijskih $i$ eksperimentalnih rezultata}

Uspešnost katapultiranja pilotskog sedišta zavisi od mnogih faktora, a jedan od presudnih u početnom delu ka-

tapultiranja je odgovarajuća brzina sedišta sa pilotom na kraju rada piropatrona i raketnog motora. Pri tome je važno da ubrzanje koje deluje na pilota bude u određenim granicama. Prosečna vrednost ubrzanja kojem je pilot izložen određuje se na osnovu ubrzanja dobijenog iz toka brzine, odnosno koeficijenta pravca krive (sl. 9), koja je dobijena obradom, odnosno integraljenjem izmerenog ubrzanja.

Rešenje diferencijalnih jednačina veoma dobro ilustruje tok kretanja sedišta pod dejstvom raketnog motora. Teorijski određena maksimalna brzina sedišta (sl. 6) na kraju rada raketnog motora razlikuje se od brzine određene obradom rezultata (s1. 9) letnih ispitivanja za oko $7 \%$, a pređeni put za oko 6\%. Ovo odstupanje je prihvatljivo i očekivano, jer brzina dobijena obradom eksperimentalnih rezultata predstavlja intenzitet apsolutne brzine sedišta u prostoru, dok je brzina dobijena rešavanjem diferencijalnih jednačina - brzina u jednoj vertikalnoj ravni, izračunata uz određene pretpostavke i uprošćenja. 


\section{Zaključak}

Pri statičkom ispitivanju raketnog motora na višekomponentnom opitnom stolu merene su tri komponente sile i tri komponente momenta. Rezultati merenja pokazali su da su glavni vektori sile i momenta upravni.

$\mathrm{Na}$ osnovu izmerenih vrednosti potiska i momenta koje ostvaruje raketni motor, kao i podataka o sedištu i pilotu, izrađen je teorijski model kretanja sedišta $\mathrm{u}$ jednoj ravni pri katapultiranju.

Eksperimentalna metoda koristi rezultate merenja ubrzanja sedišta u toku katapultiranja pilotskog sedišta, što je obavljeno pomoću lutke koja je simulirala pilota. Rezultati merenja ubrzanja se obrađuju i, na osnovu toga, dobijaju karakteristike leta sedišta.

Predložene metode, teorijske i eksperimentalne, daju rezultate koji imaju prihvatljivo slaganje.
Literatura:

1 Ganes, M.: Eject, eject, eject, FLIGHT Internacional, 9 Maj, pp. 1304-1310, 1981

2 Winn, A.: Fast exit, FLIGHT Internacional, 18-24 June, pp 56-60, 1997

3 Hewish, M.: Bringing safety down to earth, Janes internacional, defense review, N 5, pp. 48-53, 1999.

4 Rusov, L.: Mehanika I - Statika, Privredni pregled, Beograd, 1973.

5 Lazić, R.: Primena savitljivih elemenata $\mathrm{u}$ ispitivanju raketnih motora, Naučnotehnički pregled, Vol XXXIV, br. 2, pp. 19-28, 1984.

6 Kobilarev, M.: Metode obrade podataka osnovnih mernih parametara raketnih motora na čvrsto gorivo, Naučnotehnički pregled, Vol XXXII, br. 10, pp. 57-66, 1982.

7 Savković, M.: Određivanje potiska raketnog motora pilotskog sedišta na višekomponentnom opitnom stolu, Naučnotehnički pregled, Vol XLVII, br. 3, pp. 17-20, 1997.

8 Savković, M.: Analiza kretanja pilotskog sedišta u početnom periodu katapultiranja, Naučnotehnički pregled, Vol XLVIII, br. 4, pp. 26-29, 1998.

9 Nenadović, Lj.: Rezultati ispitivanja PP raketnih motora pilotskih sedišta „MB“ na višekomponentnom stolu, VTI-0301-0386, VTI Beograd, 1997.

10 Savković, M.: Ispitivanje originalnih uzoraka raketnih motora pilotskih sedišta, VTI-03-01-0350, VTI Beograd, 1994.

11 Savković, M.: Izveštaj o drugom kontrolnom ispitivanju originalnih raketnih motora pilotskih sedišta, VTI-03-010396, VTI Beograd, 1995.

12 Zarchsn, P.: Tactical and strategic missile guidance, Wachinton, 1989.

13 Savković, M.: Potisak raketnog motora pilotskog sedišta određen na osnovu ispitivanja lansiranjem sa zemlje, $\mathrm{Na}$ učnotehnički pregled, Vol LI, br. 6, pp. 95-97, 2001.

14 Savković, M.: Proizvodnja piropatrona i raketnih motora pilotskih sedišta, Vojnotehnički glasnik, br. 1, Beograd, 2006 